木村等ののべる如く冠動脈硬化の括こり方に種 族の差がなく環境の変化のみによつて差が生ず ると仮定するならば， 日本人は米国にくらべて 冠動脈硬化の極めて発現しにくい環境即ちラ， リン型の修飾因子が極めて少ない事となる。か かる観点から冲中ののべる如く日本には脳動脈 硬化の及を促進する環境因子が別に存在するか もしれない事を考虑寸る必要があろう。かかる 因子の存否に関しては脳出血の原因とともに今 後の研究にまつ所甚だ大といわねばならない。

\section{結}

\section{語}

我々は幼弱な日本猿を特に高脂肪を負荷する 事なく $\mathrm{B}_{6}$ 欠乏食慨で 10 力月以上 15 力月間 飼育して大中の各動脈のみならず小動脈, 細動
脈汇も動脈硬化性病変を作製する事が出来た。 その病変は極めて多彩な種類と程度を示したが その発症場所として心, 腎, 脺, 脾, 丵丸等の 他海汇おいても発生せしめる事が出来た。こ れらの事実から $\mathrm{B}_{6}$ 火溒の動脈硬化症の成因 は大中動脈と小動脈との間に差異はなく一元的 に考慮する事が合理的であると考える。しかし 動脈硬化発症に際して大中動脈と細小動脈では 酸性多糖体増加の態度が異る様であり, 更汇胛 部大動脈の病変には脂質代謝が重要な関連があ る樣に考える。

稿を終るにあたりこの光栄を与兄られまして尼子, 小野寺, 冲中各会長, 勝木潐備委員長汇対し深甚なる 謝意を表します。

\title{
5. 動脈硬化の成因について生化学的検討*
}

九州大学心淢血管研究施設 什村 元臣

\section{緒言}

動脈硬化の成立機序に就いては種々の面より 検討されているが，血漿成分特に脂質の変動の 面から丈では動脈硬化の病像及び発生機序を充 分に説明しにくい点がある。例えば同一個体で も各動脈により硬化の程度や病像も異り, 又同 一の動脈に於ても血管分岐部に強く起るとか大 動脈でもとの病変程度が胸部と腹部とで異なる 等の問題がある。之等の問題により一歩近づく 方法として主として私は動脈壁の代謝の面から 検討してみた。

\section{[I] 日本人屍動脈の化学的分析結果}

a) 生前の血清総コレステロール（以下コと 略す）值と動脈硬化の程度及び動脈壁の「コ」 含量との相関について。

* Supported in part by Grants-in-aid from the National Institute of Health, National Heart Institute (Grants No. H-5249 (R1)) Bethesda, U.S.A.
私共の研究室で検索した日本人虎大動脈約 100 例の中から大動脈の「コ: 含量と生前九大 附属病院及び国立筑紫病院に於てZack-柴田 法で検索された血清総「コ:を任意に 40 例と

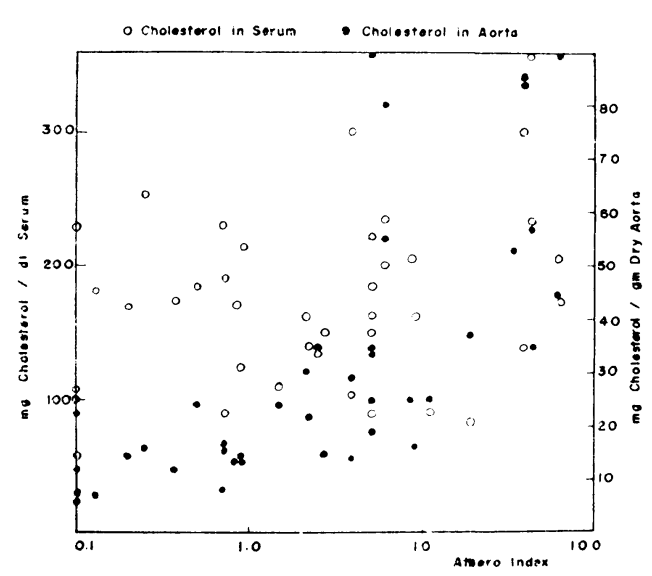

第 1 渭 Change of Japanese Cholesterol Levels in Serum and Aorta with Various Degrees of Atherosclerosis 
ウ出して比較してみると第 1 図の如く画者汇殆 んど相関をもたない事を知つた。動脈の硬化度 を Gore の Atherosclerotic Index (A. I. $)^{1)}$ で表現したときは夫々の生前血清総「コ」值と A. I. との間にも殆んど相関は見出せない。然 しこの問題は更に生前長期に亘り検索寸る必要 があると思う。

b ）動脈の脂質含有量について

日本人屍大動脈の総脂質量は A. I. の増加と 共に一般に増加する。一般に年令の増加と共に

A.I. は增加するけれども日本人に於ては 40 才迄は殆んど顕著な增加はないが，50才になる と急激に A.I. が增加し始める。但し 70 才迄 は A.I. が 5 以下の比較的正常に近いものも可 成りあるが 80 才になると殆んど A.I.は 10 を超えていた。

大動脈に含まれる全脂質量は A. I. 1.0 以下 では大動脈湿重量 $1 \mathrm{gm}$ 当り 10 乃至 $15 \mathrm{mg}$ で, A. I. が 40 になつても略々 40 乃至 $50 \mathrm{mg}$ であつた。総「コ」は大動脈脱脂乾燥重量 $1 \mathrm{gm}$ 当り A.I. 1.0 以下では $20 \mathrm{mg}$ 以下であるが A.I. が増加すると共に大動脈総「コ：日上䈍 し, 最高 $150 \mathrm{mg}$ に達した。所謂 $\mathrm{C} / \mathrm{P}$ 比も同 椂の傾向を示した。総「コ」の增加と共に「コ」 エステル比も增加した。

年令 14 才ょり 78 才迄の約 20 例の大動脈 冠動脈, 脳底動脈, 腎動脈, 左総頸動脈につい て総「コ」, A.I., 脂質分画中の総 Glycerol (G)）と脂質燐 (P) の比 $\mathrm{G} / \mathrm{P}$ を求め, 夫々 の平均值を示したのが第 2 図である。即ち同一 の個体に於ても大動脈の A. I. が最も高く, '冠, 左総頸動脈が之に次ぎ, 腎, 脳底動脈は極 めて A.I. が低い事が解る。但し茲では各動脈 に於忛るGore 指数が臨床病理学的意味に於て 妥当かどらかについてはふれない。各例の各動 脈に含をれる総「コ」の平均值は略々 A.I. の变 動の傾向と一致するが，冠動脈はより多く「コ」 を含んでいる椂にも思える。興味深い事は G/P 比が冠動脈に於て他の諸動脈と比べ数倍も高值 を示す事である。然も Glycerol 量は冠動脈に 地て脱脂乾燥組織 $1 \mathrm{gm}$ 当り平均 $10 \mathrm{mg}$ を示

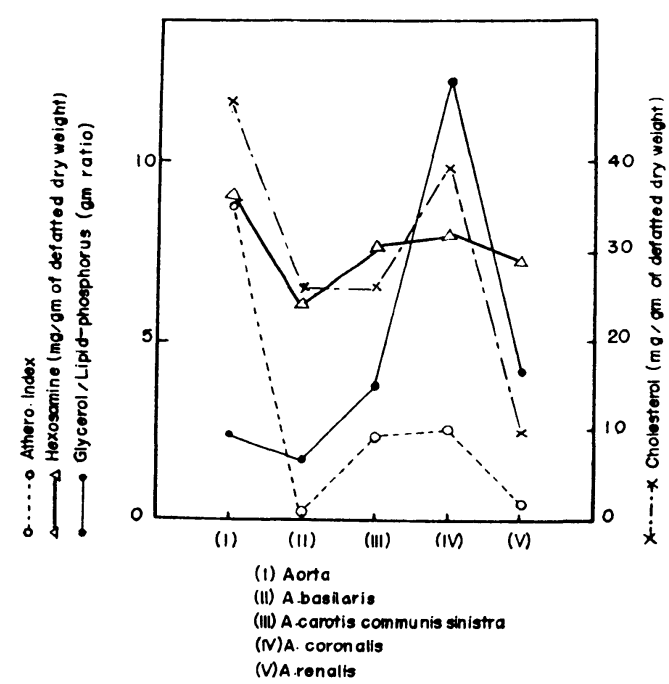

第 2 圀 Mean Value of Atherosclerotic Index and Total Hexosamin, Total Cholesterol and Glycerol-Lipid-Phosphorus Ratio in Various Arteries of Japanese.

すに反し, 脳底, 腎, 左総頸, 大動脈では夫々 $2.4 ， 2.9 ， 3.2 ， 2.3 \mathrm{mg}$ を示すに過ぎい。こ の事は冠動脈に於ては Glyceride が極めて多 い事を示している。反之, 脳底動脈或は大動脈 に於て G/P が 3.0 以下であることは Glycerol を含まない燐脂質が少くとも相対的に多い事を 示している。高脂肪食と冠硬化症との関連性や 日米両国民の死因順位に差があること即ち米人 に冠硬化症が多く且つその程度も強い事と関連 がある椂にも思われ, 今後冠動脈, 脳底動脈の 特異的代謝についてより詳細な分析的研究を行 いたいと考えている。

c ）動脈の酸性ムコ多糖体について

大動脈の外膜を除いた内, 中膜について Kirk 等の方法 ${ }^{2)}$ に準じて日本人屍 106 例の大動脈か ら酸性ムコ多糖体を精製分離定量した。精製し た酸性ムコ多糖体（以下 AMPS と略）量を脱 脂乾燥組織量 $1 \mathrm{gm}$ 当りの $\mathrm{mg}$ 数で現わすと 第 3 図に示す如く A.I. が 2.0 前後に於て稍 々平均值に於て軽度增加するが余り有意の增加 とは申しにくい。A.I. が増加するにつれ特に 20 以上となると AMPS は一般に減少する傾 向がある。勿論壊死, 潰瘍化, 石灰化部位では 


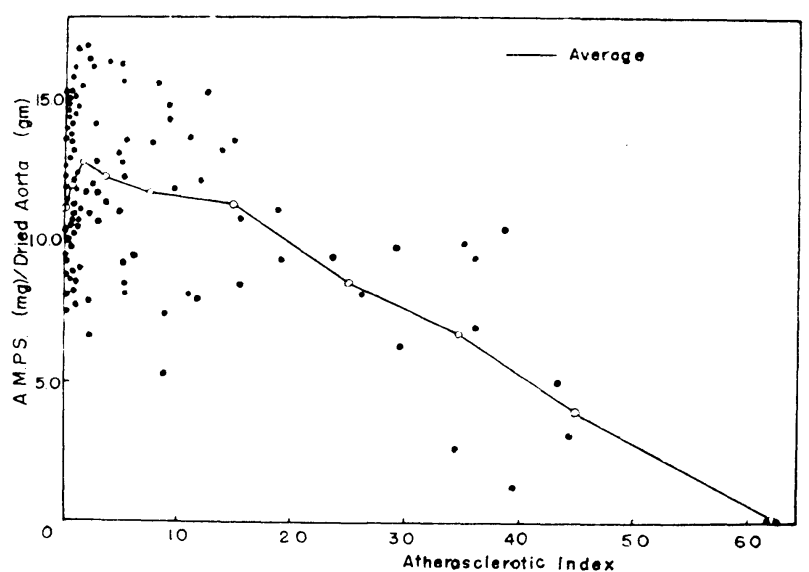

第 3 図 Correlation between Atherosclerotic Index and isolated Acid Mucopolysaccharides from Japanse Autopsied Aorta.

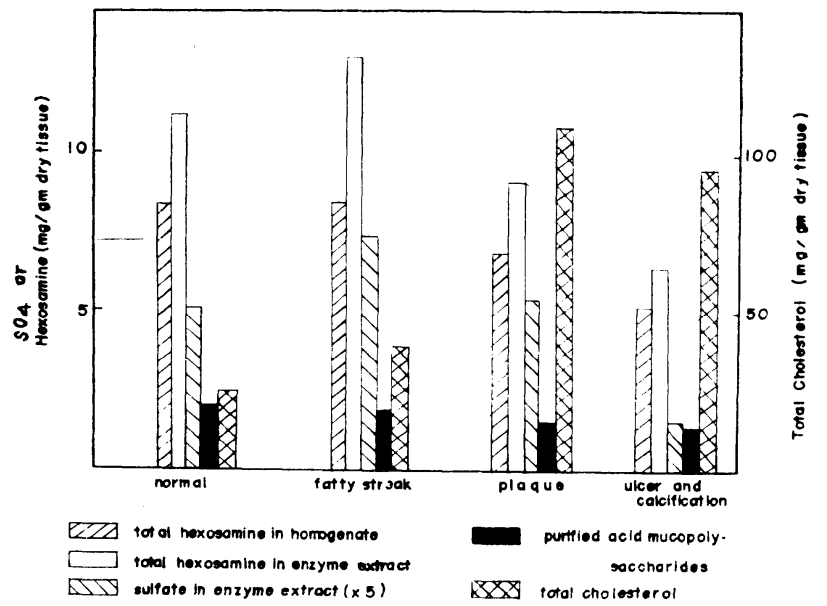

第 4 図 Acid Mucopolysaccharides and Cholesterol in Various Severity of Atheroselerotic Lesion of Japanese Autopsied Aorta.

乾燥脱脂重量が増加するからその為とも考えら れるが湿重量当りでもこの傾向は認められる。 この AMPS が減少する傾向は AMPS に含ま れるメタクロマジー陽性物質を定量した場合も 同椂に認められた。一般に AMPS には約 $80 \%$ にメタクロマジー陽性物質を含んでいた。之等 AMPSに含まれるコンドロイチン硫酸 $\mathrm{A}, \mathrm{B}, \mathrm{C}$ とヒアルロン酸や, 多糖体中間代謝産物につい ては別の機会に報告したい。

AMPS 精製分離過程に於て損失が区々であ
る事も考兄られるが一般に収量は総へ キソサミンで $25 \%$ 前後であつた。之 の AMPS 量と A.I. との関係を一 層確める為, 同一の大動脈について正 常部, 脂肪渗潤部, 線維脂肪丘, 潰瘍 石灰化部に 4 分して夫々のホモゼネー 卜，蛋白分解酵素処理後の抽出液，精 製したAMPSについて比較検討した のが第 4 図である。即ち AMPS につ いて得られた傾向は粗製品の総へキy サミン, 硫酸含量に就て子略々同様で ある事が示された。従つて大動脈の内 中膜組織について化学的に検討した範 囲では硬化の極く初期に於て AMPS は軽度増加し, 以後減少している。中 小動脈に就いて Buddeck の方法 ${ }^{3)}$ に より粗 AMPS 分画をとり，それの総 ヘキソサミンを求めた処第 2 図の如く 脳底動脈に於て他の動脈より稍々価值 を示す事を知つた。尚 Buddeck の方 法によつても大動脈硬化初期に於ての み AMPS が増加している結果を得 た。

d）動脈のアルカリ土金属について 脱脂乾燥した大動脈組織に含まれる $\mathrm{Ca}, \mathrm{Mg}$ を 40 例の日本人屍について 測定した処 $\mathrm{Ca}, \mathrm{Mg}$ 共に A.I. の增 加と共に增加する傾向にあるが，之等 アルカリ土金属の増加は A.I. より寧 ろ年令と相関して増加している。この 成績を同一の方法で測定した報告がな いので $\mathrm{Buck}^{4}$ ) の報告による欧米人の值と比較 してみると第 5 図の如く日本人に於ては Buck のい5硬化度 (H) に入るものが少いので便宜 上 A.I. 20 以上を之に入れて比較してみると， 平均年令は寧ろ私共の日本人の方が 74 才と高 令を示し, 欧米人の方が 67 才と低年を示すに 拘らず後者の群に於て $\mathrm{Ca}$ が $\mathrm{Mg}$ の增加より も極めて急増している事が知られ，日本人の場 合の増加率がのそれと略々に同じである事と対 照的である。 


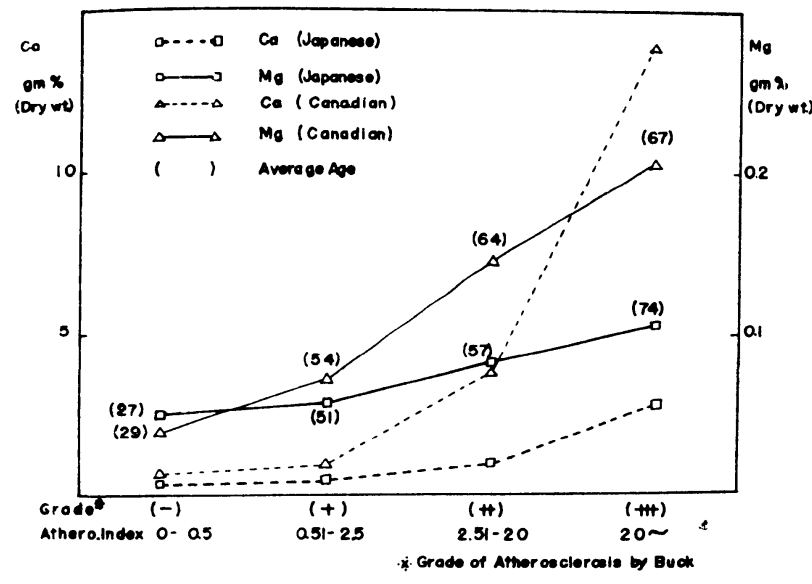

第 5 図 Calcium and Magnesium Contents in Japanese Autopsied Aorta in Comparison with Buck's Repot.

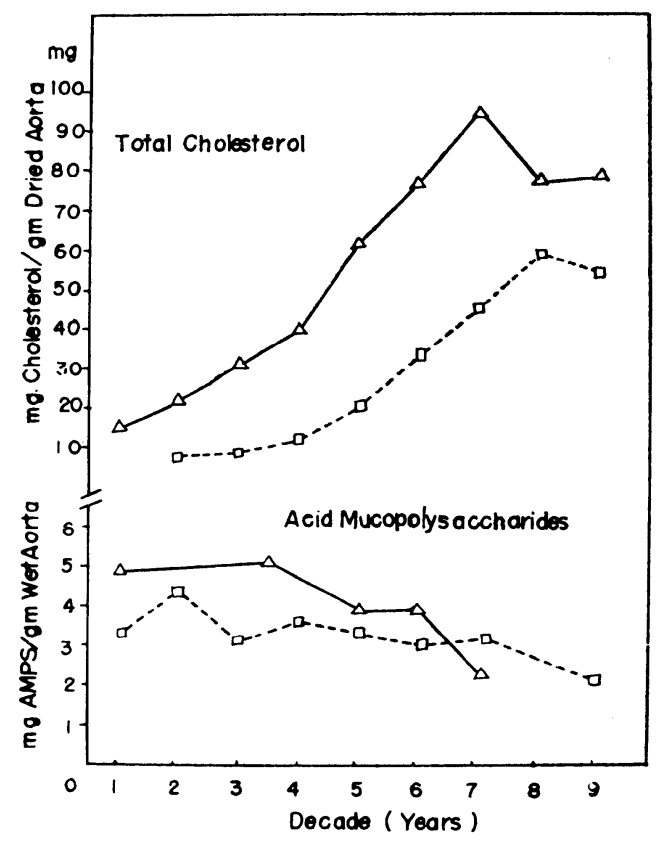

第 6 図 Chang of Cholesteroi and Acid Mucopolysaccharides by Aging in American and Japanese Auropsid Aorta.

欧米人の硬化度と日本人のそれを比べた時, 諸家の報告にもある如く ${ }^{5)}$, 一般に硬化の進展 が 10 乃至 15 年欧米人に於て先行するが大動 脈の:コ」量, AMPS 量の平均值に於ても同 漾に 10 年和くれて同様の変化即ち「コ」量の 増加とAMPS の減少が現われる（第 6 図）。

\section{[II] 動物実験的研究結果}

動脈硬化発生に演ずる動脈代謝の意義 を知る目的で血清脂質の変動が同程度で 且つ A.I. の異る実験二群として私共は $\mathrm{Mg}$ 欠乏と $\mathrm{Mg}$ 過㮃の二群を選んで用 いた。

a) 飼料性 $\mathrm{Mg}$ の実験的動脈硬化発 生に及ぼす影響について

i ) 大動脈脂質沈着度 (以下 Aorta Score, A.S. と略)

生後 5 週の雄性家种にコ」を0.25\% の割に含有する合成飼料で 3 週間飼育し 屠殺。Sudan IV 染色による A.S. を 検討した処第 7 図の如く, 飼料内 $\mathrm{Mg}$ が $5 \mathrm{mg} \%$ 以下の久, 乏群に於て明らか汇平

均 A.S. が高く現れる。

ii ) 血清脂質

$\mathrm{Mg}$ を 500 乃至 $900 \mathrm{mg}$ \% 飞含む過剩群も火 巨群も共に略々同じ血清総「コ!值分布を示し た処から血清総コ:の変動が少くともこの飼 料性 $\mathrm{Mg}$ の影響の主因とはならないと考光た。 屠殺時の血清りポ蛋白 $\beta / \alpha$ 比は両群共略々同じ

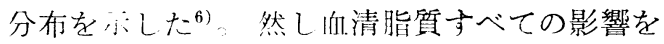
無視出来た訳ではない。即ち両群血漿 $\beta$-リポ 蛋白を超遠心分離法で分離しその中に含まれる グリセロールを定量した処各群の間では A. I. と或程度相関を示した事 ${ }^{7} や ，$ 次の実験の如く 血清総「コ」の経時的変動に於て或は腸管より の「コ」の吸収に問題が残されているからであ る。そこで欠乏群, 過剩群を 10 週飼育して行 週血清総「コ」を測定し, 10 週飼育後に屠殺し て得た A.S. と比較した処飼育開始後 3 乃至 4 週頃の血清総「コ」の高い家鬼に 10 週後の A. S. の高いもいものがある傾向が少数例の実験 乍ら得られたので，4週迄の期間に血清総「コ」 が $400 \mathrm{mg} \%$ を超支た総量即ち積分量を求めて みた処, 積分された総「コ」量の高いるのにA.S. の高い傾向が若干見られた。次に飼育開始後 3 週経て「コ」の腸管からの吸収を検討する目的 で「コ」-C $\mathrm{C}^{14}$ 投与後 6 時間と 24 時間後の血清の 総 c. p. m. と総「コ」量から Specific Activity 


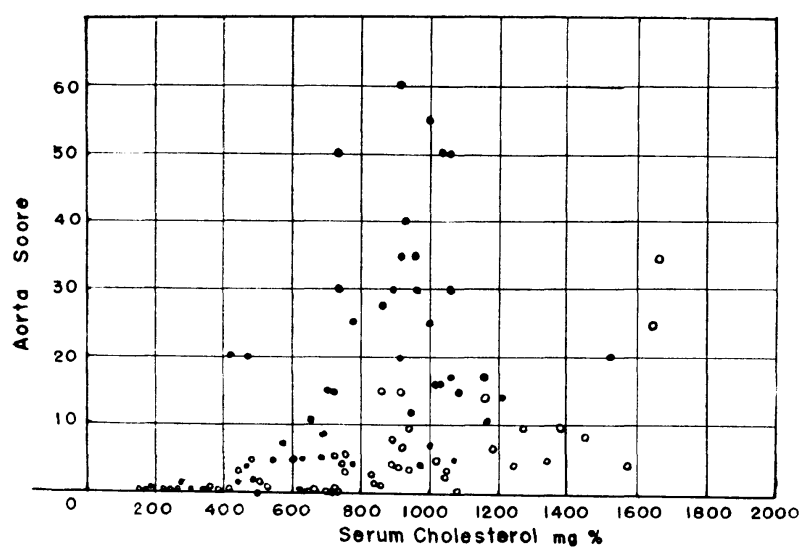

第 7 図 The relationships between vasculer sudanophilia (aortascore) and serum cholesterol level of rabbits fed a diet containing $0.25 \%$ cholesterol and $3 \mathrm{mg} \%$ magnesium or $900 \mathrm{mg} \% \mathrm{mag}$ nesium for 21 days.

: Rabbits fed a diet containing $3 \mathrm{mg}$ magnesium and $0.25 \%$ cholesterol.

- Rabbits fed a diet containing $90 \mathrm{mg} \% \mathrm{ma}$ gnesium and $0.25 \%$ cholesterol.

を求めた処， 6 時間後は勿論 24 時間後の Specific Activity \& A.S. とは殆んど相関を示 さなかつた。唯総「コ」量と c. p.m. との間 には軽度の相関がみられた。

この他血清, 心筋のリポ蛋白リパーゼ活性を 測定してみなが両群の間に明らかな差異を見出 し得なかつた

一力生後 3 週経心ラッテに atherogenic の 飼料を 4 週間与えて斉らされるA.S.はそそ後 半年乃至 1 年後 Plaque 形成に進展するが ${ }^{8}$,

この 4 週飼育後の A.S. は Mg の最小要求量 とされる $24 \mathrm{mg} \%$ の 8 倍量を与える事により 抑制される。然しこの場合血清 $\mathrm{Mg}$ の軽度乍 ら低下すること，腎細尿管内石灰沈着，心筋の 酸性的燐酸化の低下等が認められた事よりラッ テに於ても寧万 $\mathrm{Mg}$ 久乏状態に於て脂質沈着 が増加したと考えている。之等ラッテ, 家鬼に 対する $\mathrm{Mg}$ 欠乏時の大動脈脂質沈着の増強は, 血清総「コ」量, リポ蛋白 $\beta / \alpha$ 比, 等から丈で は説明出来ないので以下の如く大動脈の代謝を 検討してみた。

iii）実験動物の大動脈壁代謝
生後 3 週経たラッテに $\mathbf{M g}$ 欠乏食 を与えると 3 乃至 4 週頃より次第に大 動脈の $\mathrm{Qo}_{2}$ が低下し，それにつれて $\mathrm{P}^{32}$ の大動脈壁 ATP 及び燐脂質への とりこみが低下して来る事を認めた。 同時に $\mathrm{Mg}$ 久乏ラッテ大動脈では $\mathrm{S}^{35}$ のコンドロイチン硫酸へのとりこみも 低下して来る事を知つた。

之等の $\mathrm{Mg}$ 欠乏ラッテ大動脈のエ ネルギー代謝に伴ら燐酸化合物生合成 の低下をラッテの老化時と比較してみ る為, 生後 4 週, 4 力月, 12力月経た 純系 Donryu 系雄ラッテ大動脈壁内 $\mathrm{ATP}$ と燐脂質への $\mathrm{P}^{32}$ のとりこみを 検討した。即ち 12 カ月経たラッテ大 動脈に於ては $\mathrm{Qo}_{2}$ が軽度低下し, ATP 燐脂質分画への $\mathrm{P}^{32}$ のとりこみが著減 している事を知つた。之等を模式的に 表すと第 8 图の如くなる。

$\mathrm{Mg}$ 欠泛動物ではこの他分光学的測定や, 電

\section{Abnormal Energic Motabolism of Arterial Wall} in Magneslum Deticiency and Aging
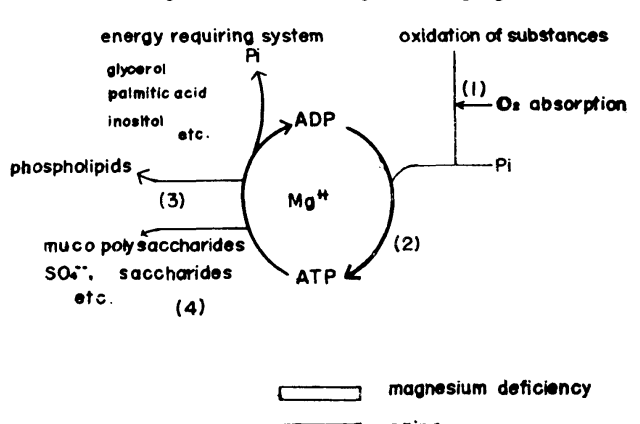

एय aging

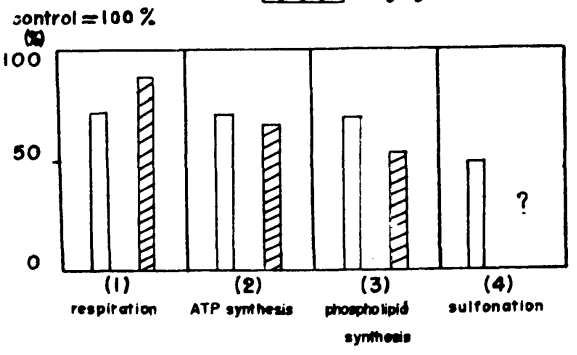

第 8 图 Abnormal Energie Metabolism of Arterial Wall in Magnesium Deficiency and Aging. 
子顕微鏡的観察により心朌ミトコンドリアの膨 化と共に $\mathrm{P} / \mathrm{O}$ 比の低下が認められる事 ${ }^{9}$, 廔 々腎細尿管内石灰沈着, 血管中膜の石灰化 ${ }^{8)}$, 心筋壊死 ${ }^{6)}$ が認められており，一般に $\mathrm{Mg}$ が燐 酸化の必須要素である点とる関連して考兄ると $\mathrm{Mg}$ 欠乏動物ではエネルギー生成及び燐酸化能 力の低下が考えられる。老化時の大動脈に於て もよく之と似た所見が得られた事より目下の処 考えられる推測として次の様になると思われ る。

機能の面から細胞を細胞膜乃至それより派生 した構造と核とに二分すると，細胞膜はリポイ ドと蛋白及び $\mathrm{Ca}$ 或は $\mathrm{Mg}$ の二価イオンとか ら成立つているので之等りポイドと蛋白の結合 に燐脂質が重要な役割をしている事が考兄られ る。「コ」が細胞膜の之ら rigid な構成の中間 に存在しているとすれば，燐脂質生合成の低下 は「コ」の蓄積性に作用することも考えられる。 或はエネルギー生成, 燐酸化の低下から細胞膜 の透過性が六進した為に脂質沈着が起り易くな つたとも考える事が出来よ5。 $\mathrm{Mg}$ 欠乏家鬼に

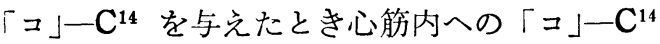
のとりこみが対照群のそれより大きい事も之と

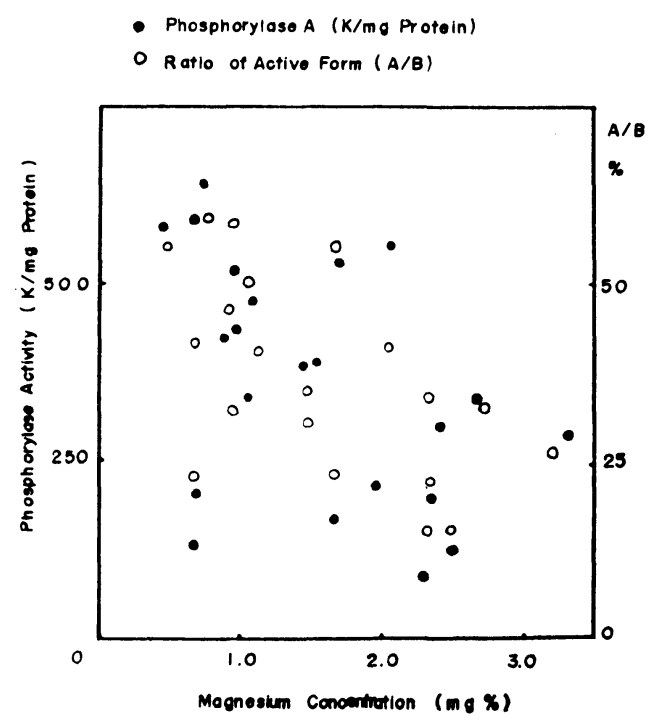

第 9 脑 Magnesium Concentration in Serum and Phosphorylase Activity in Skeletal Muscle.
関連して考えてみると興味深いと思う。老化 に際しても恰もェネルギーの生成, 燐酸化の Uncoupling があるかの如く思われた点もこの 点に興味をとえるるのと思う。勿論之等は一応 の説明に止まるものである。

$\mathrm{Mg}$ 欠泛ラッテではこの他第 9 困の如く學骼 筋 Phosphorylase の活性型（A）が增加して いる。血清 $\mathrm{Mg}$ 值の低下につれて活性型（A) 乃至その割合 (A/B) が増加する。この事はラ ッテの pair feedingを行つても認められた処 より単なる摂取カロリーの不定によるものとは 考えにくく，この酵素が 3'-5'-cyclic AMP に より賦活される事を考えるとき $\mathrm{Mg}$ 欠乏時の カテコールアミン， ACTH 等ゆ副腎ホルモン 系の異常に今後研究の発展を期している。

次に人体屍大動脈の分析からは脂質沈着が最 初か， AMPS の变化が最初かは明らか炕し得 なかつたので，実験的に家鬼の急性高 ב，血 症を作り,電顕的に極〈一部 High density 物 質が内皮細胞膜或いは細胞体内にとりこまれて いる時期を選んで $\mathrm{S}^{35}$ のコンドロイチン硫酸へ のとりこみを検討してみた。この様な時期には 多くの場合内皮細胞下層の拡大が認められるが Specific activity に於て明らかに $S^{35}$ のとり こみが堌大している結果を得る事が出来なかつ た。

家鬼大動脈の代謝を検討する場合大動脈は想 像以上に器械的障害に弱いと思われる。例えば とり出した大動脈を開いてピンセットで十数回 つまむ位で酸素吸収の低下， $\mathrm{S}^{35}$ のコンドロイ チン硫酸へのとりこみが低下寸る事から（第 1 表), 大動脈䟝離の仕様, 標品の作り方に今後 解決されるべき問題も残されていると思う。之 等の点が解決すれば血圧, 血流の変動による動 脈の代謝障碍も解決され, 更には大動脈と中小 細動脈夫々の代謝が解つてくればより一層動脈 硬化の発生機序が明らかとなるだろう。高血圧 の問題には今回ふれる事が出来なかつたのは高 血圧により起る細小動脈の変化を未だ生化学的 にとりあげる事が分析する方法論的に解決し得 なかつた為である。 
第 1 表

Effect of mechanical damage on respiration of into chondroitin sulfates of rabbit aorta

\begin{tabular}{|c|c|c|c|}
\hline & & control & damaged \\
\hline \multirow{4}{*}{$\mathrm{Qo}_{2}$} & & 0.43 & 0.39 \\
\hline & & 0.49 & 0.23 \\
\hline & & 0.45 & 0.23 \\
\hline & & 0.43 & 0.31 \\
\hline \multirow{6}{*}{$\begin{array}{l}\text { Specific Activity } \\
\text { (c. p. m./r of } \\
\text { chondroitin } \\
\text { sulfates of } \\
\text { rabbit aorta) }\end{array}$} & Av. & 0.45 & 0.29 \\
\hline & & 1. 31 & 0.95 \\
\hline & & 1.81 & 0.57 \\
\hline & & 2.52 & 0.65 \\
\hline & & 1. 85 & 0.62 \\
\hline & Av. & 1.87 & 0.69 \\
\hline
\end{tabular}

Conditions : Aorta of rabbit 500 to $680 \mathrm{mg}$ (wet weight), Ringer-phosphate solution $2.7 \mathrm{ml}$., $0.1 \mathrm{ml}$ of $1 \mathrm{M}$ Gluose solution, $\mathrm{Na}_{2} \mathrm{~S}^{35} \mathrm{O}_{4} 400$ uc. ; $0.2 \mathrm{ml}$. of 15 $\% \mathrm{KOH}$ in center well of Warburg flask ; $36^{\circ} \mathrm{C}$., air ; $60 \mathrm{~min}$. incubation

\section{[III] お わりに}

人体動脈硬化の発生機序を知るためには自律 神経ホルモン更には大脳生理等より高次な機能 生化学の斫究が行われなければ病態生理的解明 は望めないだろう。然し'卧ら末だ動脈壁自体の 代謝及び化学的物質の変動が充分に分析されて いない現在，私共は今後更により詳細な分析を 細小動脈に至る迄行つてみたいと思う。

校を終るに臨み本シンボジウム参加の機会をお与 之戴いた小野寺会長, 勝木準備委貣長に深謝します。 淌この研究は中谷こ佐子, 佐々木猛, 迫良治, 鼠井紳 一郎, 平松幹敏, 太田敏郎, 平野順造, 梅崎敬夫, 玉 利一博, 佐田禎造, 石原保之, 藪田討子, 木村節子等 の共同研究によつた。終りに貴重な解剖屍動脈を惠与. された九大病理学第一, 第二..講座, 国立筑紫病院, 熊 本大学病理学教室に深謝します。

\section{文献}

1) Gore, I. A. E. Hirst, Jr, and Y.Koseki : Am. J. Clin. Nutr. 7, 50 (1959).

2) Dyrbye, M. J.E. Kirk : J.Geront., 12, 20(1957).

3) Buddecke, E. : Biochem. Z., 310, 171 (1958).

4) Buck, R.C. : Arch. Path. 5, 319 (1951).

5) 玉利一博：医学研究，32，23 (1962).

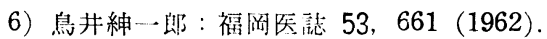

7) 中村元居，他：Symposium. Chem. Physol \& Path. 1, 69 (1961).

8) 中村元臣他 : J. Nutrit., 71，347 (1960).

9) 中村元臣他 : Proc. Soc Exy. Biol. \& Med., 108, $315(1961)$

\begin{tabular}{ll}
\hline 討 & 議 \\
\hline
\end{tabular}

\section{䉼弝硬化成因の Key Mechanism と} しての浮腫性反応（岛本等）

\section{大型動脉と小型動䐂 (細動脉) との構} 造上の相違並びに籿状硬化生起物質 に対する反応の相違について

\section{東京医科歯科大学}

島本多喜雄 須水俊明 滕田 勉

大動脉を電子顕微的に見ると他の臓器組織に 見られない特徵がある。即ち内膜では内皮細胞 と内弾性板との間, 中膜では平滑筋と弾性線維 との間に内径 $19,000 \sim 70,000 \AA$ に達する極め て広いとして不規則な形の extracellular spaces が存在する事実である。然も我々が先 に報告した如く䉼状硬化生起物質投与により特 舅的,一過性に浮腫性動脉反㐫を起し,この $\mathrm{ex}-$ tracellular space が更に増大し之に弾性線維 の離開, collagen fibril の分散, 内皮表面への 栓球粘着及び光学顕微鏡的に該部への $\alpha$ 調 metachromasia の増強を伴ない又同時に流血 蛅着性栓球の激減と血液凝固性儿進を来す。

(Asian Med. J. 4 : 309，1961)。我々はこの 動脉の浮腫性反忍を中心とする一連の反応を码 状硬化成因の key mechanism と考えてい る。その理由の第一は Rockitansky, Duguid による粥状硬化成因の血恮説の支えとなつてい る病理解剖学的諸事奏奏に又 Anitschkov 以 来の cholesterol 仮説の支えとなつている諸事 奏を浮腫性動脉反忘は幽者を併せて叮成り良く 説明し得る。第二の根拠は浮腫性動脉原応を起 するのはその慢性投方により動物に料状硬化学 起す事が出来ることを挙げたい。な搔力では ないが浮腫性動脉反心を玄防うる楽物の一つで ある nialamide は実験的粥状破化を或程度 